\title{
The Covid-19 Between State of Emergency and Exception in Italy and Its Consequences on Human Rights
}

\author{
Marco Omizzolo \\ Sociologist at Eurispes and president of "Tempi Moderni"
}

Pina Sodano

Sociologist, Ph.D. in Political Science, vice-president of the Study Centre "Tempi Moderni"

\begin{abstract}
In mid-December 2019, several atypical cases of pneumonia were detected in hospitals in Wuhan City - Hubei Province - in Inner China. It turns out that the first patients had already fallen ill in early December or even midNovember. However, only on the last day of the year 2019, Chinese doctors were able to officially identify a new virus in a 41-year-old patient admitted 5 days earlier. The virus belongs to the class of "coronavirus", the same to which the SARS (Severe Acute Respiratory Syndrome) and MERS (Middle East Respiratory Syndrome) viruses belong. It is initially baptized 2019-nCov, or "new 2019 coronavirus". In February, the official name assigned to the virus is Sars-COV-2 and the associated disease is named COVID-19. The outbreak took on considerable proportions in China and then spread to the rest of the world, leading the World Health Organization to declare the infection a "pandemic" on 11 March 2020. The containment strategies applied in the most affected countries have proved to be very different in effectiveness, to the point that the lethality of the virus appears very different from country to country. This difference in impact has led to different legal, economic and social consequences.
\end{abstract}

Keywords: Covid-19, State of Emergency, Exception in Italy, Consequences, Human Rights

\section{Introduction}

On 21 February, a secondary outbreak was also detected in Italy, i.e. the transmission did not only affect people from areas at risk. The first Italian COVID-19 patient was detected in Codogno (Lodi). After an attempt to isolate a "red zone", Italy has been facing a progressive national lockdown since March 7. With a series of measures in succession - the subject of this essay - the government has stopped increasingly large 
portions of the productive fabric, until it identified a small number of "essential activities" that could continue the activity, including the agricultural supply chain.

The Italian government has also followed the WHO guidelines for the surveillance of the epidemic. The contagion in the Lombardy region immediately appeared very widespread and the tests carried out were not sufficient to accurately monitor the phenomenon. At the end of March 2020, the epidemic in Italy caused about six thousand infections per day and about one thousand victims. Overall, there were over ten thousand victims and 92 thousand infected people identified through 429 thousand tests. As Walter Scheidel recalls in his extensive review on inequality (Scheidel, 2019), epidemics are among the most transformative events in human history. The crisis triggered by the Sars-COVID-2 epidemic and the choices made to combat it, has produced strong pressure on the protection, international and national, of human rights. The High Commissioner for Human Rights, Michelle Bachelet, said, "Given the exceptional nature of the crisis, it is clear that states need additional powers to address it. However, if the Rule of Law is not respected, the health emergency risks becoming a human rights catastrophe, the adverse effects of which will far outweigh the pandemic itself (Editorial staff MeteoWeb, 2020). The corona virus pandemic, contrary to popular belief, also kills healthy adults, as well as older people with previous problems. WHO data say that the global mortality rate of the virus has doubled in the last two months, from $2.1 \%$ on 20 January to $4.4 \%$ on 23 March, well above $2 \%$ of the well-known "Spanish" pandemic.

Sars-COVID-2, together with the dramas it has caused, is also an unprecedented test for Europe, just a few months after Brexit. After the initial torpor, the lives of European citizens have changed dramatically under the pressure of measures like never before, in times of peace. More than 250 million people have experienced a situation of total or partial lockdown, with measures affecting the fundamental rights of human beings, which are at the basis of Western democracies, and represent the expression of an awareness that emerged following the dramatic experiences of the European dictatorships of the early 20th century and the Second World War.

From this point of view, the debate on how to deal with Sars-COVID-2 developed, in its first phase, along two different axes: the first concerned the treatment of the patients, the second the containment of the epidemic. The United Kingdom and other countries proposed the first, which British Prime Minister Johnson exemplified in his famous statement on herd immunity. The second, however, is the one adopted by South Korea and Taiwan. It should be pointed out that the first system led to dramatic consequences in terms of the number of deaths, particularly in the weakest section of the population, in view of substantial respect for rights and democratic life of the country. The second system, which tended to protect the population as a whole, had inevitable consequences in terms of respect for human rights. 
On a closer analysis, the situation appears to be much more complex than previously considered, to the point that, by taking those two alternatives to the extreme, we cannot help but notice some disturbing points of convergence. The strategy developed by Korea and Taiwan - i.e. moderate containment - so different from the Chinese model and its European variants, has led to a much smaller restriction of the rights of the citizens, also due to the efficiency with which the strategy has been conducted. On the other hand, the radical solutions to the epidemic have called into question the system of rights and the democratic order itself. There are several dramatic examples in support of this thesis: for example, Hungary officially declared a state of emergency to allow a centralised management of the health emergency, but the first application of the extraordinary powers given to Prime Minister Orban (Benvenuti, 2020; De Sena, 2020) was the repeal of the law allowing for the registration of sex change ${ }^{1}$. On the other hand, equally worrying are the news coming from Brazil, where President Bolsonaro, who is probably infected with the virus, passes through the crowd calling for a coup d'état; not to mention groups of armed citizens who gather in various US cities, praising President Trump against the "strong powers" who have practiced the lockdown.

In this perspective, the decisional practice established in Italy during the months of the emergency deserves careful analysis in order to understand both the genesis and future prospects and the possible repercussions on the system of fundamental rights and guarantees.

\section{Sars-Covid 2 and the Italian Constitution}

Unlike most of the European continent, the Italian Constitution does not provide for a state of emergency. It merely lays down provisions, in Article 78, for the declaration of a state of war. The Constituent chose not to take into consideration the proclamation of a state of emergency in order not to create dangerous precedents, such as to reopen the way to authoritarian drifts. Only decades later, the Italian legislator decided to include the state of emergency in art. 24 of the Civil Protection $\mathrm{Code}^{2}$, and this is an evolution to be analyzed with great attention, also for its repercussions in terms of social protection.

According to par. 1 of this instrument, "on the occurrence of the events which, following an expeditious assessment carried out by the Civil Protection Department on the basis of available data and information, and in connection with the Regions and Autonomous Provinces concerned, meet the requirements of Article 7, paragraph 1,

\footnotetext{
1 This choice reveals the mythical/sacral origin of the operation: in emergencies, the leader takes up again the primordial role of medium between the human and the divine; his task is then to appease the divine wrath, through the restoration of the "boni mores". Unfortunately, there is a reappearance of an ancient and terrible logic, as it is taking place in Hungary.

2 Legislative Decree no. 1, 02/01/2018, in G.U. no. 17, 02/01/2018.
} 
letter c) ${ }^{1}$, i.e. the Council of Ministers - on the proposal of the President of the Council of Ministers, formulated also at the request of the President of the Region or Autonomous Province concerned and, in any case, having acquired the agreement deliberates the state of emergency of national importance, fixing its duration and determining its territorial extension with reference to the nature and quality of the events and authorises the issuing of the civil protection orders referred to in Article 252 ." The fact that the compression of rights is possible by means of ordinances "in compliance with the general principles of EU law and regulations" indicates that the measure, in the intentions of the legislator, is not intended to exceed the limitations laid down in the Constitution on the application of individual rights (Civinini and Scarselli, 2020) ${ }^{3}$.

With regard to the Sars-Covid-2 epidemic, the Italian Government declared the State of Emergency on 31 January 2020 in terms that did not allow predicting what would have happened later. The preamble of the Declaration makes general reference to a serious international crisis, which manifested itself with the proclamation of a state of global emergency by the WHO on 30 January. The Head of Civil Protection would have carried out the necessary implementation of the measures, in accordance with Article 25 of Legislative Decree 1 of 2018.

After the Declaration of 31 January, Regional Governors and Mayors issued a series of ordinances - in addition to the orders of the Head of Civil Protection -, which led to serious legal and social confusion. The ordinance is the instrument of the President of the Region (and in some cases the Mayor) as well as the head of Civil Protection but, in a state of emergency, the latter is supposed to prevail.

The Government intervened with Decree-Law No 6 of 23 February on 'Urgent measures on containment and management of the epidemiological emergency by COVID-19', converted, with amendments, into Law No 13 of 5 March. The decree-law

\footnotetext{
${ }^{1}$ Article 7, paragraph 1, letter c) identifies "emergencies of national importance connected with natural or man-made calamitous events which, due to their intensity or extent, must, with immediate intervention, be faced with extraordinary means and powers to be used during limited and predefined periods of time pursuant to Article 24".

${ }^{2}$ According to the Article 25 (par. 1), the coordination of the implementation of the interventions during the state of emergency takes place through the ordinances of the Civil Protection, "in derogation of any existing provision, within the limits and in the manner indicated in the deliberation of the state of emergency and in compliance with the general principles of the legal system and the rules of the European Union". The ordinances shall be issued after agreement with the Regions and Autonomous Provinces territorially concerned and, if they derogate from the laws in force, they shall contain an indication of the main rules to which they intend to derogate, with specific reasons.

${ }^{3}$ After a careful reading of Articles 24-25 of the Civil Protection Code, the opinion expressed by the President of the Court of Pisa and Prof. Scarselli seems reasonable. In fact, they claim, "These measures are clearly designed to deal, for example, with an earthquake or flood, but not with a viral pandemic such as the one we are experiencing". Civinini, V. and Scarselli, G. (2020). Emergenza sanitaria. Dubbi di costituzionalità di un giudice e di un avvocato, Questione giustizia, Research news.
} 
provided that, considering the worsening of the situation, the government should intervene with containment measures implementing the declaration of the state of emergency taken with DPCM, after consultation with the relevant ministers and regional presidents. The decree-law was followed by a series of Prime Ministerial decrees implementing it on 23 February, 25 February, 1 March, 4 March (which imposed suspension for certain kinds of activities at a national level, through absolute bans and criminal sanctions) and 8 March (which tightened the measures both in the red zone and at national level).

The restrictive aspect of the measures contained in the Prime Ministerial Decrees took a quantum leap with the Prime Ministerial Decree of 9 March, which was further amended by the subsequent Prime Ministerial Decrees of 11 March and 22 March. It should also be noted that Decree-Law No 19 of 25 March 2020 extended until 13 April the measures initially taken until 3 April. The Decree-Law was also used in some sectors for the regular conclusion of the school year, for economic measures and to reorganise the whole Country for the restart.

To date, the measures relating to the restriction/suspension of rights have been taken through DPCM - and Ministerial Decrees -, issued on the basis of an ordinary law - Law no. 13 of March 5 converting Decree-Law no. 6 of February 23 (and subsequently Decree-Law no. 19 of March 25) -, which applied the declaration of a state of emergency more than a month earlier.

The question that arises concerns the appropriateness of the procedure followed in Italy, considering the enormous impact that the measures have had on fundamental human rights. This is without prejudice to the assessment of the severity of the epidemic itself, and does not consider how the virus could have manifested itself with such destructive effects in Italy, as well as in France, Spain, the United Kingdom and Belgium (as well as in the USA and Latin America), while little has occurred in Taiwan, South Korea and a number of other European countries ${ }^{1}$. In order to answer this question, the existing instruments of international protection of human rights must be analysed as a framework for the qualification of the government choices under examination.

\section{International protection of human rights and their derogation}

Both the ECHR (European Court of Human Rights) and the PDCP (International Covenant on Civil and Political Rights) contain a provision derogating from the protection of human rights, respectively in Article 15 of the first and Article 4 of the second, and this under the conditions set out in paragraphs 3 of both instruments. The provision in paragraph 1 of both instruments indicates the conditions under which a State may suspend the application of the rights provided for in the instrument

${ }^{1}$ Germany but also other Northern European countries and beyond (see Portugal). 
itself ${ }^{1}$. The central aspect of the strict formulation of the possibility of emergency derogation ${ }^{2}$ in international human rights law should not be sought in the provision of such a possibility. It is a measure present "also in other conventional texts, to signify the irrepressible impulse of the State to act free from constraints when, in situations of force majeure and/or extreme danger, its security or even its existence is at stake". The central aspect of this formulation is that the States allow the possibility of unilateral recourse to the derogation to be limited ${ }^{3}$.

In suspending the application of the Treaty to which it refers, the derogation clause should not be confused with restrictive clauses which serve to limit the specific scope of certain provisions. In particular, Articles 5 and 8 to 11 ECHR - which deal with the right to personal freedom, respect for family life, freedom of thought, conscience and religion, freedom of expression, freedom of assembly and association - are constructed on the basis of a recurrent scheme, according to which the right is set out in paragraph 1, while paragraph 2 sets out the restrictive measures in the application of the law to which the State may have recourse. Thus Article 5(2) (e) states, among the reasons justifying the regular detention of a person, that of 'preventing the spread of a contagious disease'. Given that the only restrictions on the normal exercise of the right of assembly and association must be laid down by law, Article 11 indicates such measures as necessary in a democratic society 'for national security, public order, the defence of law and order and the prevention of disorder and other offences, the protection of health and morals, and the protection of the rights and freedoms of others'. Article 9(2) provides for a similar limit for the freedom to manifest one's religious beliefs. Article 2 of Protocol 4 to the ECHR is still relevant. It relates to freedom of movement, and indicates that the regular exercise of that freedom may be restricted only for compelling reasons, provided for by law, such as restrictions that constitute "measures that are necessary for national security ... for the protection of health, in a democratic society"4. At the end of Title I, Rights and Freedoms, Article 18

\footnotetext{
${ }^{1}$ According to Article 15 (1) ECHR, the State, "in the event of war or other public danger threatening the life of the nation, may take measures derogating from the obligations laid down in this Convention to the strictest extent that the situation requires", "as far as there is no contradiction with other obligations under international law". In stricter terms, Article 4 (1) PDCP seeks to deal with an exceptional public danger threatening the very existence of the nation, and it sets as a condition that it must be proclaimed by means of an official act.

${ }^{2}$ Article 15 (3) ECHR requires the State to inform the Secretary General CoE when the state of emergency begins and when it comes to an end.

3 Zagato, L. Ibid. The Commission, and then the EDU Court, have established that the situation referred to in paragraph 1 is in the meantime a situation of crisis or exceptional danger, since it poses a threat "pour la vie organisée de la communauté composant l'Etat en question": EDU Commission, Lawless v. Eire, Decision of 30 August 1958, in YECHR, II, 1958-59; EDU Court Lawless v. Eire, 1 July 1961, Rec. 332/57.

4 Protocol No 4 to the Convention for the Protection of Human Rights and Fundamental Freedoms recognize some rights and freedoms not included in the Convention and its Additional Protocol,
} 
ECHR provides that restrictions on freedoms may only be imposed 'for the purpose for which they were intended'. Articles 18 par. 3 (freedom of religion) and 21-22 par. 2 (freedom of assembly and association) of the PDCP express the same concept in rather close terms, while Articles 12-13 confirm freedom of movement for anyone who is legally in a State other than his own, as well as to leave the country where he is, including his own. All these rights are subject only to the restrictions provided by law, necessary to protect national security, public order, public health and morality, or the rights and freedoms of others, compatible with the other rights recognized by the Pact itself.

Ultimately, as long as a State puts in place measures restricting individual rights that do not go beyond what is provided by the limiting clauses of the ECHR or PDCP, whether or not it declares a state of emergency, it does not have to make any notification. On the other hand, when the measures taken go beyond, or concern rights in relation to which the Treaty does not provide for restrictive measures, only the notification (to the CoE Secretariat or to the UN Secretariat) of the proclamation of the state of emergency will protect the State from the consequences of its actions.

In the present crisis, ten European countries have used Article 15 ECHR to justify the measures taken at national level ${ }^{1}$. The form of these notifications ${ }^{2}$ suggests that these states, when taking emergency measures, made the notification in the uncertainty of the possible consequences. They followed the footspeps of Georgia, which notified the state of emergency declared at the time of the avian epidemic in $2006^{3}$.

In fact, as there was no reaction in the ECHR to the declaration of a state of emergency during the avian influenza epidemic - certainly less dangerous than Sars-COVID-2 - it was to be expected that the same would happen in the case of the current epidemic. All the more surprising then is that Italy has not done so. It is true that the Italian State, like every other State, can deal with situations of serious danger as it sees fit, but it is also clear that only recourse to the notification procedure provided for in Article 15(3) ECHR would have demonstrated the concern on the Italian side to ensure that, even in dealing with such a serious crisis, the limitations of fundamental rights remained within the limits of what was strictly necessary.

Strasbourg, 16 September 1963, entered into force internationally on 2 May 1968, in Italy on 27 May 1982.

${ }^{1}$ Starting with the Note Verbale notified by Latvia to the Secretary General CoE on 16 March 2020.

These are: Albania, Armenia, Azerbajan, Estonia, Georgia, Latvia, North Macedonia, Moldova, Romania, Serbia.

2 Summary E., "Law enforcement measures ...", cit., such as the use of the formula that the measures adopted "may invoke a derogation from certain obligations" indicates the absence of absolute certainty on the part of the notifying States as to the scope of the measures taken, or any amendments that may be necessary in the course of the procedure.

${ }^{3}$ Note verbale notified to the Secretary-General CoE on 13 March 2006. 
Other countries belonging to the Convention also proclaimed a state of emergency without notification, because some States did not initially take any measures (UK, Netherlands), but were then forced to follow the events (UK in particular, while the Netherlands remained within the limits of restrictive measures). Other States adopted measures prepared in good time, so that they were able to tackle the crisis by means of measures that were restrictive, but not suspensive of rights (Germany, Portugal). From this point of view, it is even more difficult to justify the French ${ }^{1}$, Spanish $^{2}$ and, above all, Italian lack of notification of the state of emergency.

\section{The Italian case in phase 1}

In Italy, passive behaviour in the first weeks after the declaration of the emergency may explain the initial lack of notification. It remains that subsequent measures, in particular since the Prime Ministerial Decree of 9 March, are unlikely to fall within the scope of the ordinary restriction of individual and collective freedoms. In other words, they do not simply restrict the rights of movement, assembly, association, work and economic initiative. These measures also seriously interfere with the exercise of other rights: worship, education ${ }^{3}$, family life and, above all, the right to freedom, both individual and collective, to privacy and scientific freedom. The ratio behind these measures lies in the protection of the right to health: art. 32 of the Constitution states thathealth is a fundamental right of the individual as well as the community, stressing that no one can be subjected to health treatment except by legal obligation, with the only limit of respect for human dignity.

The point is that the confinement measures taken from 8-9 March in Italy have in fact paralyzed, to the point of suspending it, that right of freedom, placed not by chance (Article 13) at the beginning of Title I (civil relations) of Part One of the Constitution, "Rights and duties of citizens". This establishes that personal freedom is inviolable and cannot be restricted except by reasoned act of the judicial authority and only in the cases and ways provided for by law. The public security authority may take any provisional measures only in cases strictly provided for by law, which must in any case be examined by the judicial authority within 48 hours, forfeited in the event of failure to validate them. Some constitutionalists have explained that Art. 13 cannot yield to Art. 32 (Pace, 1974) ${ }^{4}$. It is astonishing, then, that in a situation constitutionally

\footnotetext{
1 Proclaimed by Prime Minister Edouard Philippe on 18 March 2020.

2 Proclaimed by Prime Minister Sanchez on 14 March 2020.

3 Provided for in Article 2 of the Additional Protocol to the Convention for the Protection of Human Rights and Fundamental Freedoms, Paris, 20 March 1952, entered into force on 18 May 1954, in Italy on 26 October 1955.

4 Pace, A. (1974) Libertà personale (dir. Cost.), in Enc. Dir,: "It should be immediately stated that it does not seem that art. 13 can give way to art. 32; therefore all coercive restrictions for health reasons must necessarily follow the jurisdictional route provided for by that article" (p. 298), and in even more direct terms (p. 296), "on the other hand, the public authority could never invoke art. 32 of the
} 
so much at risk, the opportunity to link the Italian emergency practice with the international instruments referred to, has not been taken into account.

International human rights law does not include this strange game between state of emergency and state of exception. Within the context of the present crisis, Hungary is the only European country to have actually used the declaration of the state of emergency for liberticidal purposes, and it has beware of notifying it, unlike the ten states that proclaimed the state of emergency in relation to the measures taken against the epidemic. Furthermore, in the context of the international system, in which Italy is also included, there must always be an emergency fact at the origin of the suspension of rights (EDU Commission, 1969).

In conclusion, the Italian legislator has never foreseen an emergency such as the one that has arisen, thus skewing a rule, Article 24 of the Civil Protection Code, which has little to do with this situation. It is no coincidence that from the very beginning the Italian media have used the metaphor of war and not that of natural disasters to explain the suspension of fundamental rights. As for the fact that the measures taken in application of the state of emergency went beyond the limits of the simple restriction of rights ${ }^{1}$, this is evident at least in relation to Articles 13 and 17. Finally, one may wonder to what extent the provision suspending all non-urgent judicial activities, including the substantial closure of judicial offices, is compatible with Article 24 of the Constitution.

\section{The Italian case in phase 2}

With the transition into Phase 2, concerns about constitutionally contrived human rights procedures increase. First, the questionable absolute prevalence given to the right to health over any other right tends to turn into absolute prevalence of the precautionary principle, increasing doubts about its constitutionality. Perplexities have increased since the television announcement by the Italian Prime Minister Giuseppe Conte on 25 April, which, based on this principle, imposed uniformity of treatment for situations in different realities, each relating to fundamental rights.

It should be noted that, on the one hand, the ongoing projects for phase 2 seriously affect the right to privacy. Specifically, the introduction of tracking apps via DPCM without parliamentary debate raises serious concerns, especially in relation to the perverse relationship between emergency legislation and technological innovation. In this respect, the google/apple agreement, due to its global scope, is more than just

Constitution to derogate, for health reasons, from the scope and guarantees of art. 13": contribution cited, with others, in Civinini M.G., Scarselli G., op.cit.

1 See the open letter of 30 jurists (lawyers and professors, but also the President of the Juvenile Court) from Turin to Premier Conte on 29 April 2020, with the indicative title "Restore constitutional guarantees", in https://www.open.online/2020/04/29/ripristinare-garanzie-costituzionali-letteraaperta-premier-conte-trenta-giuristi-torinesi/. 
one example among others on which a thorough critical analysis needs to be undertaken.

On the other hand, the role of the media in the "war against the coronavirus" campaign - responsible for an uncertain congruity with that art. 33 of the Constitution that wants art and science free, and free their teaching - has not been sufficiently analysed. It has consolidated, in fact, the unique thought in a field where opinions among specialists differ. The predominant thesis was total and prolonged imprisonment, waiting for the vaccine as the only solution, propagation of a state of anxiety and fear to be managed by vague media reassurance, interruption of any opinion that diverged from the standard narrative. This dangerous trend has led the Guarantor for Telecommunications to invite the social media to obscure sites that carry "inaccurate news or news not coming from authoritative scientific sources". If it is true that fake news is circulating on the web, it is equally true that, the way the measure is presented, it seems dangerously aimed at silencing the voices of scientific dissent.

On the opposite side, the insistent demand to put an end to measures to return to a normal situation as quickly as possible represents a shortsighted vision, unable to grasp the changed threshold of the problems at all levels of civilised living, including respect for human rights.

\section{In conclusion: fundamental freedoms have been violated and new horizons have emerged}

The most important aspect of the impact of radical containment of the epidemic on human rights is that it has affected the freedom of our living as a whole, not only individual aspects. It has affected all rights, not some specific ones, but has also created new horizons. Actually, the collective character of some human rights emerges, in the present situation, with a force that was not conceivable before. One of these rights, in particular, which has long remained a prisoner of an uncertain status, draws unthinkable strength from what we might call a heterogenesis of purpose. In fact, since the epidemic caused the worst damage in the most polluted areas (especially in those zones with a high concentration of fine dust), and since it sprang from the perverse dynamics that compromise both natural environments and its species, now the public authorities have - at least in theory - to take environmental factors into account for their purposes of recovery. In the meantime, a series of measures to protect the environment had already been planned - at both European and national level - in terms of the ecological conversion of the economy and the construction of circular economy dynamics, but these measures have now come to a standstill. However, in Italy as elsewhere, the executive has to maintain certain fixed points in order to give faith to its own narration of the emergency. In fact, the incentive measures for the purchase of bicycles and scooters are a truly significant turning point for Italy, and Paris itself shows an exponential growth of pedestrian 
areas and cycle paths, in phase 2. Indeed, the environmental component of the right to health and the environmental dimension of the right to life are the areas coming out of the crisis that are most requalified.

The other right that emerges is the right to cultural heritage and identity, which is both an individual ${ }^{1}$ and a collective right. That is to say, the right of the community to keep its identity profiles alive (Zagato, 2012), and the right to safeguard the cultural identity of the community, as a heritage of humanity. The collective dimension of cultural rights and the right to cultural identity does not conflict with the individual dimension of the rights themselves. "The collective dimension develops through and thanks to the individual one; besides, recent international legal instruments" (Zagato, 2017) include in particular the Convention on the Protection of Intangible Heritage at a universal level ${ }^{2}$ and the Faro Convention ${ }^{3}$ at a regional level. The collective dimension of safeguard of cultural heritage closely relates to the practice of sharing and transmitting of knowledge ( Pinton, S. and Zagato, L. n.d.), but the accelerated digitisation of recent months poses a serious threat in the field of education, such as the impulse to cultural standardisation. It is therefore essential to recover a dialogical, as well as a physical profile of the social relationship in the dimension of cultural transmission. However, after the experiences of the last few months, communities and movements within civil society know that they must deal with the construction of digital archives in relation to their respective identity profiles, and with the setting up and the application of digital museums. In short, we must not disperse the forced legacy of the lockdown. Today we must make a creative effort, also in relation to language, since "we urgently need new metaphors and new words to draw the days we are living; the old ones risk turning not only the present into a nightmare, but also and above all, the future that awaits us" (Cassandro D., 2020).

\section{Bibliography}

[1] Azzariti, G. (2020, March, 27th) I limiti costituzionali della situazione d'emergenza provocata dal Covid-19, in Questione Giustizia, https://www.questionegiustizia.it/articolo/i-limiti-costituzionali-dellasituazione-d-emergenza-provocata-dal-covid-19_27-03-2020.php

[2] Caravita, B. (2020, March 18th) ) L'Italia ai tempi del coronavirus: rileggendo la Costituzione italiana, in Federalismi.it,

[3] Cassandro, D. (2020, March, 22nd), Siamo in guerra! Il coronavirus e le sue metafore, in Internazionale,

\footnotetext{
${ }^{1}$ It refers to the right of individuals belonging to ethnic, religious or linguistic minorities to have a cultural life of their own, in common with other members of their group, to profess and practice their religion or to use their language.

${ }^{2}$ Convention for the Protection of Intangible Heritage, Paris, 27 October 2003, entered into force internationally on 20 January 2006, in Italy.

3 Faro Convention on the value of cultural heritage for society, Faro, 13 October 2005, entered into force internationally on 1 June 2011, not yet for Italy (proceedings in progress).
} 
https://www.internazionale.it/opinione/danielecassandro/2020/03/22/coronavirus-metafore-guerra

[4] Cavino, M. (2020, March 18th) Covid-19. Una prima lettura dei provvedimenti adottati dal Governo, in Federalismi.it, https://www.federalismi.it/ApplOpenFilePDF.cfm?artid=41287\&dpath=doc ument\&dfile=17032020173454.pdf\&content=Covid\%2D19\%2E\%2BUna\%2 Bprima\%2Blettura\%2Bdei\%2Bprovvedimenti\%2Badottati\%2Bdal\%2BGov erno\%2B\%2D\%2Bstato\%2B\%2D\%2Bpaper\%2B\%2D\%2B

[5] Civinini M.G., Scarselli G. (2020, Avril 14th) Emergenza sanitaria. Dubbi di costituzionalità di un giudice e di un avvocato, in http://questionegiustizia.it/articolo/emergenza-sanitaria-dubbi-dicostituzionalita-di-un-giudice-e-di-un-avvocato_14-04-

200.php?fbclid=IwAR1jnbzhJ5UnQZIOCs8JZBAHqhNFW3EVCNz3pyX6Zvs8Q BNvPsRHFOMvcVs

[6] Clementi, F. (2020, March, 13th) Quando l'emergenza restringe le libertà meglio un decreto legge che un Dpcm", in Il Sole 24 Ore, http://www.google.com/url?q=https://www.c3dem.it/wpcontent/uploads/2020/03/quando-lemergnza-restringe-lalibert $\% 25 \mathrm{C} 3 \% 25 \mathrm{~A} 0$-fr-clementi-

sole.pdf\&sa=U\&ved=2ahUKEwiC76nYlOPqAhXHqaQKHeMzBYUQFjABegQIC RAB\&usg=AOvVaw2nNPsTi_EYYoHNExUEmHm1

[7] D'Aloia, A., (2/2020), Costituzione ed emergenza. L'esperienza del coronavirus, in $B L J$, http://www.google.com/url?q=https://www.biodiritto.org/Online-FirstBLJ/Online-First-BLJ-2-20-Instant-Forum-Diritto-diritti-ed-emergenza-aitempi-del-Coronavirus\&sa=U\&ved=2ahUKEwjfmMb1lOPqAhWIaQKHbp2Df0QFjAAegQIABAB\&usg=AOvVaw0G3AQoCljPPUz2hi7gKlir

[8] De Nes, M. (2/2020) Emergenza covid-19 e bilanciamento di diritti costituzionali: quale spazio per la legalità sostanziale?", in $B L J$, http://www.google.com/url?q=https://www.biodiritto.org/Online-FirstBLJ/Online-First-BLJ-2-20-Instant-Forum-Diritto-diritti-ed-emergenza-aitempi-del-

Coronavirus\&sa=U\&ved=2ahUKEwixq9qYlePqAhURDOwKHQjXB_MQFjABeg QICBAB\&usg=AOvVaw11peDVVRvs1uPiDK9FOWkT

[9] EDU Commission, (1969) report 5 November 1969 (Greek case), in Yearbook ECHR, vol. XII.

[10] https://www.federalismi.it/nv14/editoriale.cfm?eid=548

[11] Pinton, S. and Zagato, L., Sulla persistente difficoltà di assicurare la partecipazione delle comunità nella salvaguardia del patrimonio culturale, in particolare dei saperi tradizionali, in Rievocazioni storiche - un patrimonio da salvaguardare, Sopraintendenza Archeologica, Belle Arte e Paesaggio per il territorio di Venezia e Laguna, Venezia, currently being published. 
[12] Raffiotta, E.C. (2/2020) Sulla legittimità dei provvedimenti del Governo a contrasto dell'emergenza virale da coronavirus, in $B L J$, http://www.google.com/url?q=https://www.biodiritto.org/Online-FirstBLJ/Online-First-BLJ-2-20-Instant-Forum-Diritto-diritti-ed-emergenza-aitempi-del-Coronavirus\&sa=U\&ved=2ahUKEwic3NK8lePqAhVS3KQKHXGCHAQFjAAegQIARAB\&usg=AOvVaw3YFYLRyZnMCjWe8arvHOYl

[13] Ravì Pinto, R. (2/2020) Brevi considerazioni su stato d'emergenza e Stato costituzionale, in $B L J$, http://www.google.com/url?q=https://www.biodiritto.org/content/downlo ad/3827/45443/version/1/file/44\%2BRavi\%2BPinto.pdf\&sa=U\&ved=2ah UKEwiKztjYlePqAhWCCOwKHb9AAcQFjAAegQIARAB\&usg=AOvVaw1ZkptcXO_9SSNRZ-B8_BW2

[14] Scheidel, W. (2019) La grande livellatrice: violenza e disuguaglianza dalla preistoria a oggi, Bologna, Il Mulino.

[15] Zagato, L, (2017) (In-)tangible Cultural Heritage as a World of Rights?, in S., Zagato L., Cultural Heritage. Scenarios 2015-2017, Venice, Ed. Ca' Foscari Digital Publishing.

[16] Zagato, L. (2012) Intangible Cultural Heritage and Human Rights, in (edited by), Scovazzi, T., Ubertazzi. B. Zagato L.. Il patrimonio culturale intangible nelle sue diverse dimensioni, Milan, Giuffré, pp. 39-50. 